\title{
A lecture experiment on diathermancity
}

\section{Dr. Silvio Lussano}

To cite this article: Dr. Silvio Lussano (1896) A lecture experiment on diathermancity, Philosophical Magazine Series 5, 42:255, 208-208, DOI: 10.1080/14786449608620908

To link to this article: http://dx.doi.org/10.1080/14786449608620908

$$
\text { 曲 Published online: } 08 \text { May } 2009 .
$$

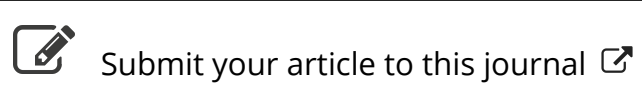

\footnotetext{
Џll Article views: 3
}

Q View related articles $\longleftarrow$ 
action on the coherer; and hence the arrangement was used for some quantitative determinations.

The refractive indices of a series of solid and liquid substances were determined. The following values were obtained for the wavelength in question corresponding to a value of $\mathrm{N}=37.500 \times 10^{6}$.

\begin{tabular}{|c|c|c|}
\hline Paraffine . . . . . . . . . & $n=1 \cdot 524$ & $n^{2}=2 \cdot 32$ \\
\hline Ebonite ...... & 1.739 & $3 \cdot 02$ \\
\hline Crown-glass $\ldots \ldots \ldots \ldots$ & $2 \cdot 381$ & $5 \cdot 16$ \\
\hline Flint-glass $\ldots \ldots \ldots \ldots$ & $2 \cdot 849$ & \\
\hline Sulphur . . . . . . . . & $1 \cdot 802$ & 3 \\
\hline Benzole $\ldots \ldots \ldots$ & $1 \cdot 767$ & $3 \cdot 1$ \\
\hline Glycerine . . . . . . . . & $1 \cdot 843$ & $3 \cdot 4$ \\
\hline Oil of turpentine ..... & $1 \cdot 782$ & $3 \cdot 17$ \\
\hline Vaseline ......... & $1 \cdot 626$ & \\
\hline Oil of almonds .. & $1 \cdot 734$ & \\
\hline Absolute alcohol .... & $2 \cdot 568$ & \\
\hline Distilled water ...... & $8 \cdot 972$ & 80 \\
\hline
\end{tabular}

-Wiener Berichte, July 1896.

\section{A LECTURE EXPERIMENT ON DIATHERMANCITY.}

BY IR. SILVIO LUSSANO.

A very simple and elegant method of showing to a large audience the transparency or opacity of bodies for calorific radiations is the following, which is based on the change of colour some substances experience by variations of temperature.

Double iodide of silver and mercury is prepared in a fine powder. At the ordinary temperature it has a beautiful canary-yellow colour, changing to a purple-red at the temperature of about $49^{\circ}$, and resuming its original colour when cold. This double iodide is prepared by mixing in molecular proportions the two substances $\mathrm{HgI}_{2}$ and $2 \mathrm{AgI}$, then adding to the mixture alcohol which partly dissolves the mercuric iodide; the magma is then well stirred together in a mortar, alcohol being added from time to time. The mixture, which at first is red, then changes to orange, and, after some time, becomes of a canary-yellow colour; the alcohol is allowed to evaporate, the magma being stirred all the time.

The double iodide thus prepared is spread on cardboard, forming a screen of a canary-yellow colour sensitive to calorific radiations. If, then, this is placed below a metal ball strongly heated, the colour of the screen changes, showing the heating due to the radiations. The same thing takes place if a plate of ebonite is interposed between the ball and the screen; but if a plate of a substance opaque to thermal radiations is placed on the ebonite, the shadow of this plate is projected on the screen, showing a yellow colour on a red ground. In this way it can be understood that it is easy to obtain the projections of athermanous substances enclosed between two ebonite plates.-Communicated by the Author from 'Il Nuovo Cimento,' May 1896. 